\title{
TINGKAT LITERASI DIGITAL MAHASISWA KEGURUAN DALAM MENGHADAPI ERA REVOLUSI INDUSTRI 4.0
}

\author{
Umar, Hendra, Mei Indra Jayanti \\ IAI Muhammadiyah Bima, STKIP Bima \\ Email:laodeumarpgmi@gmail.com
}

\begin{abstract}
Abstrak
Literasi digital merupakan suatu kemampuan soft skill yang selayaknya dimiliki mahasiswa guna menghadapi era revolusi industri 4.0. Sehubungan dengan hal tersebut, penelitian ini bertujuan untuk mengidentifikasi tingkat literasi digital mahasiswa keguruan dilihat dari aspek persepsi terhadap literasi digital, keterpaparan terhadap penggunaan teknologi digital, dan harapan terhadap pengembangan literasi digital. Penelitian ini merupakan penelitian lapangan (field research) yang bersifat kuantitatif. Populasi dalam penelitian ini adalah seluruh mahasiswa keguruan pada Prodi PGMI Fakultas Tarbiyah Institut Agama Islam (IAI) Muhammadiyah Bima, berjumlah 128 orang. Sampel dipilih dengan menggunakan teknik stratified random sampling sehingga diperoleh 30 mahasiswa sebagai sampel penelitian. Hasil penelitian menunjukan bahwa tingkat literasi digital mahasiswa keguruan Prodi PGMI Fakultas Tarbiyah Institut Agama Islam (IAI) Muhammadiyah Bima dilihat dari aspek persepsi terhadap literasi digital berada pada kategori sedang (63\%), aspek keterpaparan terhadap teknologi digital menempati kategori rendah (33\%), dan untuk aspek harapan terhadap pengembangan literasi digital masuk pada kategori sedang (42\%).
\end{abstract}

Kata Kunci: Literasi Digital, Mahasiswa, Revolusi Industri 4.0

\section{Pendahuluan}

$P$ erkembangan teknologi informasi saat ini telah menghadapkan manusia pada pola hidup yang serba cepat dan mengharuskan seseorang agar dapat meningkatkan pengetahuannya selaras dengan perubahan jaman. Tuntutan perubahan jaman tersebut ditandai dengan beragamnya temuan teknologi informasi seperti; smartphone, komputer, laptop, aplikasi media sosial, maupun jaringan internet yang dapat menunjang akses kehidupan manusia, baik dalam bentuk komunikasi maupun interaksi tanpa ada batas ruang dan waktu. Pada sisi lain, perkembangan teknologi informasi menjadi basis pengembangan konsep revolusi industri 4.0 diseluruh dunia. Hal ini turut mempengaruhi paradigma sosial kehidupan masyarakat termasuk di Indonesia. Era revolusi industri 4.0 merupakan fase revolusi teknologi yang mengubah cara beraktifitas manusia dalam skala, ruang lingkup, kompleksitas, dan transformasi dari pengalaman hidup sebelumnya. Manusia bahkan akan hidup dalam ketidakpastian (uncertainty) global, oleh karena itu manusia harus memiliki kemampuan untuk memprediksi masa depan yang berubah sangat cepat. 
Tiap negara harus merespon perubahan tersebut secara terintegrasi dan komprehensif. Respon tersebut dengan melibatkan seluruh pemangku kepentingan politik global, mulai dari sektor publik, swasta, akademisi, hingga masyarakat sipil sehingga tantangan industri 4.0 dapat dikelola menjadi peluang. ${ }^{1}$

Era revolusi industri menekankan manusia bukan sekedar sebagai pengguna industri tetapi harus mampu menempatkan diri sebagai pencipta sekaligus menjadi creator dalam memanfaatkan teknologi industri secara inovatif. Kondisi inilah yang menurut segenap elemen masyarakat untuk meningkatkan pemahaman literasinya terutama literasi digital dalam memanfaatkan teknologi informasi guna mengembangkan potesi diri dalam kehidupan sosial. Paul Gilster dalam Indah Kurnianingsih, menjelaskan bahwa literasi digital sebagai kemampuan memahami dan menggunakan informasi dari berbagai sumber digital. Ia mengemukakan bahwa literasi digital merupakan kemampuan menggunakan teknologi dan informasi dari piranti digital secara efektif dan efisien dalam berbagai konteks, seperti akademik, karier, dan kehidupan sehari-hari. ${ }^{2}$

Di Indonesia saat ini, perkembangan jumlah media tercatat meningkat pesat, yakni mencapai sekitar 43.400, sedangkan yang terdaftar di Dewan Pers hanya sekitar 243 media. Dengan demikian, masyarakat lebih mudah mendapatkan informasi dari berbagai media yang ada, terlepas dari resmi atau tidaknya berita tersebut. Hal ini terindikasi dari semakin merosotnya budaya baca masyarakat yang memang masih dalam tingkat yang rendah. Kehadiran berbagai gadget yang bisa terhubung dengan jaringan internet mengalihkan perhatian orang dari buku ke gadget yang mereka miliki. Perkembangan media digital juga memberikan peluang, seperti meningkatnya peluang bisnis e-commerce, lahirnya lapangan kerja baru berbasis media digital, dan pengembangan kemampuan literasi tanpa menegasikan teks berbasis cetak. Selain itu, jenis lapangan pekerjaan yang memanfaatkan dunia digital semakin bertambah, seperti ojek atau taksi daring, media sosial analisis, dan pemasaran media sosial. ${ }^{3}$

Namun, menurut Qory Qurratun A'yuni permasalahan perkembangan dan kemajuan teknologi internet menyebabkan penggunaan TI yang berlebihan di kalangan remaja perkotaan. Salah satunya yaitu pemanfaatan internet untuk

\footnotetext{
${ }^{1}$ Muhammad Yahya, Era Industri 4.0: Tantangan dan Peluang Perkembangan Pendidikan Kejuruan Indonesia.Pidato Pengukuhan Penerimaan Jabatan Professor Tetap dalam Bidang Ilmu Pendidikan Kejuruan Fakultas Teknik Universitas Negeri Makassar, 2018.

${ }^{2}$ Indah Kurnianingsih, dkk. "Upaya Peningkatan Kemampuan Literasi Digital bagi Tenaga Perpustakaan Sekolah dan Guru di Wilayah Jakarta Pusat Melalui Pelatihan Literasi Informasi (JPKM 2017), 62-63.

${ }^{3}$ Departemen Pendidikan Nasional.Materi Pendukung Literasi Digital. (Jakarta: Kementrian Pendidikan dan Kebudayaan, 2017)
} 
menelusur informasi yang tidak sesuai dengan usia dan dilakukan bukan atas dasar kepentingan tetentu. Selain itu, pemanfaatan jejaring sosial saat ini lebih banyak dilakukan pada motif identitas personal, dalam artian lebih ditekankan pada proses membangun relasi dengan orang lain. Hal ini dilakukan dengan cara memperbarui status atau saling menimpali komentar maupun foto yang diunggah dalam akun jejaring sosial yang dimilikinya. Seharusnya kemajuan teknologi internet dapat lebih digali dan dimanfaatkan semaksimal mungkin untuk keperluan yang lebih bermanfaat, misalnya meningkatkan kemampuan kognitif dan psikomotor dalam menggunakan media digital ataupun melakukan pencarian informasi terkait tugas akademik. Akibatnya, banyak sekali ditemukan kasus-kasus yang tidak diinginkan terjadi dewasa ini, mulai dari cyberbullying, cybercrime, hingga kekerasan seksual di kalangan remaja. ${ }^{4}$

Berdasarkan uraian di atas, penelitian ini dimaksudkanuntuk mengidentifikasi kemampuan literasi digital khusus dikalangan para mahasiswa dalam menghadapi era revolusi industri 4.0. Kondisi ini dikarenakan, mahasiswa merupakan kelompok masyarakat ilmiah, yang diharapkan dapat menjadi elemen pembaharu bagi pemanfaat literasi digital dilingkungan masyarakat yang lebih luas. Di samping hal tersebut, adanya kemampuan mahasiswa dalam memahami literasi digital turut mempengaruhi kompetensi dalam diri para mahasiswa dalam menghadapi tuntutan dan peruhahan zaman di era revolusi industri 4.0. Sejauh pengetahuan penulis, penelitian tentang tingkat pemahaman literasi digital mahasiswa relatif masih belum banyak dilakukan, apalagi dihubungkan dengan asas pemanfaatan literasi digital dalam menghadapi era revolusi industri dikalangan mahasiswa, kecuali penelitian yang berhubungan dengan literasi digital dikalangan remaja seperti penelitian yang dilakukan Qory Qurratun A'yuni mengenai literasi digital remaja di Kota Surabaya. Dalam kesimpulannya bahwa tingkat literasi kompetensi digital remaja di Kota Surabaya berada pada kategori tinggi, sedang dan rendah.

Lebih lanjut, ia mengungkapkan kemampuan literasi digital kalangan remaja di Kota Surabaya dapat diklasifikasi berdasarkan 4 aspek sebagai berikut: tingkat literasi digital remaja berdasarkan aspek internet searching sudah tergolong tinggi, tingkat literasi digital remaja berdasarkan aspek hypertextual navigation sudah tergolong tinggi, tingkat literasi digital remaja berdasarkan aspek content evaluation masih tergolong sedang, serta tingkat literasi digital remaja berdasarkan aspek

\footnotetext{
${ }^{4}$ Qory Qurratun A'yuni, Studi Deskriptif tentang Tingkat Kompetensi Literasi Digital pada Remaja SMP, SMA dan Mahasiswa di Kota Surabaya (Departemen Informasi dan Perpustakaan, Fakultas Ilmu Sosial dan Ilmu Politik, Universitas Airlangga Surabaya).
} 
knowledge assembly sudah tergolong tinggi. ${ }^{5}$ Senada dengan hal itu, dalam artikel yang ditulis Dyna Herlina S, menjelaskan bahwa teknologi digital telah tersebar luas namun masih banyak orang yang belum dapat memanfaatkan teknologi ini secara produktif. Penyalahgunaan teknologi digital dapat berdampak buruk bagi kehidupan pribadi dan sosial. Oleh karena itu, literasi digital perlu dikembangkan untuk membangun karakter bangsa. Dimensi literasi digital meliputi alat dan sistem, informasi dan data, berbagi dan kreasi, konteks sejarah dan budaya. Melalui pemahaman terhadap dimensi- dimensi tersebut dapat dikembangkan materi dan metode pembelajaran literasi digital di sekolah dan luar sekolah.$^{6}$

Penelitian ini memiliki beberapa tujuan yaitu; Pertama, untuk mengetahui persepsi mahasiswa terhadap literasi digital dalam mengahadapi era revolusi industri. Kedua, untuk mendeskripsikan keterpaparan para mahasiswa dalam menggunakan teknologi digital era revolusi industri. Ketiga, untuk mengungkapkan gambaran harapan para mahasiswa terhadap pengembangan literasi digital di era revolusi industri. Hasil penelitian ini nantinya diharapkan dapat berguna untuk memberikan informasi deskriptif kuantitatif tingkat literasi digital mahasiswa kuhususnya mahasiswa keguruan dalam menghadapi era revolusi industri 4.0. Kemudian dari sudut pandang ilmu pendidikan, penelitian ini diharapkan juga dapat berguna sebagai landasan empirik dan sosilogis bagi civitas akademik perguruan tinggi, terlebih lagi perguruan tinggi keguruan guna meningkatkan pemahaman literasi digital mahasiswa terhadap pentingnya pemanfaat literasi digital dalam mengahadapi era revolusi industri 4.0. Dengan demikian, keluaran/ouput perguruan tinggi akan memiliki kualifikasi serta kesiapan kompetensi yang cukup memadai dalam menjawab tantangan dan perubahan jaman yang semakin dinamis dalam kehidupan sosial masyarakat.

\section{Hakikat Literasi Digital}

Perkembangan teknologi digital telah menjadi bagian yang tidak terpisahkan dalam aktivitas kehidupan masyarakat modern di seluruh dunia, termasuk Indonesia. Dinamika digitalisasi seolah menjadi sarana penghubung "tanpa batas, tanpa sekat wilayah terotorial" bagi seseorang untuk melakukan berbagai interaski dalam kehidupan sosialnya, baik berupa interaksi komunikasi, interaksi antar budaya, interaksi ekonomi, maupun interaski yang besifat politik antar bangsa dengan tujuan untuk memahami satu dengan yang lainnya secara global. Kondisis inilah yang menjadi dasar penting bagi seseorang untuk memahami dan mengetahuai makna

\footnotetext{
${ }^{5}$ Ibid.,

${ }^{6}$ Dyna Herlina S, Membangun Karakter Bangsa melalui Literasi Digital.pdf.
} 
literasi digital di era revolusi industri 4.0. Sehubungan dengan hal tersebut, Menurut Paul Gilster dalam bukunya yang berjudul Digital Literacy sebagaimana dikemukan Kementrian Pendidikan dan Kebudayaan dalam modul Gerakan Literasi Nasional menjelaskan bahwa literasi digital diartikan sebagai kemampuan untuk memahami dan menggunakan informasi dalam berbagai bentuk dari berbagai sumber yang sangat luas yang diakses melalui piranti komputer. Senada denngan hal itu, Bawden juga menawarkan pemahaman baru mengenai literasi digital yang berakar pada literasi komputer dan literasi informasi. Literasi komputer berkembang pada dekade 1980-an, ketika komputer mikro semakin luas dipergunakan, tidak saja di lingkungan bisnis, tetapi juga di masyarakat. Namun, literasi informasi baru menyebar luas pada dekade 1990-an manakala informasi semakin mudah disusun, diakses, disebarluaskan melalui teknologi informasi berjejaring. Dengan demikian, mengacu pada pendapat Bawden, literasi digital lebih banyak dikaitkan dengan keterampilan teknis mengakses, merangkai, memahami, dan menyebarluaskan informasi. ${ }^{7}$

Pandangan senada juga dikemukan Hague dalam Indah Kurinasih, dkk., menguaraikan bahwa literasi digital merupakan kemampuan untuk membuat dan berbagi dalam mode dan bentuk yang berbeda; untuk membuat, berkolaborasi, dan berkomunikasi lebih efektif, serta untuk memahami bagaimana dan kapan menggunakan teknologi digital yang baik untuk mendukung proses tersebut. Selanjutnya, Indah Kurinasih, dkk., juga menyimpulkan bahwa karakteristik literasi digital tidak hanya mengacu pada keterampilan operasi dan menggunakan berbagai perangkat teknologi informasi dan komunikasi teknologi (perangkat keras dan platform perangkat lunak), tetapi juga untuk proses "membaca" dan "memahami" sajian isi perangkat teknologi serta proses "menciptakan" dan "menulis" menjadi sebuah pengetahuan baru. ${ }^{8}$

Dengan demikian menurut hemat penulis, literasi digital sesungguhnya dapat dipahami sebagai kompetensi softskill yang semestinya dimiliki dan dikuasai oleh seseorang dalam penggunaan serta pemanfaatan perangkat teknologi digital sebagai media informasi dan komuniaksi, media pembelajaran, media transaksi usaha dan ekonomi, media pertukaran social-budaya, maupun politik antar bangsa. Pada akhirnya, kecakapan literasi digital dalam diri seseorang akan mengarah pada lahirnya kemampuan daya cipta dan inovasi guna mengahadapi perkembangan jaman sepertinya halnya menjawab tantangan perubahan jaman di era revolusi 4.0.

\footnotetext{
${ }^{7}$ Departemen Pendidikan Nasional, Materi Pendukung Literasi Digital (Jakarta: Kementrian Pendidikan dan Kebudayaan, 2017).

8Indah Kurnianingsih, dkk. "Upaya Peningkatan Kemampuan Literasi...,62-63.
} 


\section{Prinsip Dasar Pengembangan Literasi Digital}

Menurut UNESCO konsep literasi digital menaungi dan menjadi landasan penting bagi kemampuan memahami perangkat-perangkat teknologi, informasi, dan komunikasi. Misalnya, dalam Literasi TIK (ICT Literacy) yang merujuk pada kemampuan teknis yang memungkinkan keterlibatan aktif dari komponen masyarakat sejalan dengan perkembangan budaya serta pelayanan publik berbasis digital. Literasi TIK dijelaskan dengan dua sudut pandang. Pertama, Literasi Teknologi (Technological Literacy) sebelumnya dikenal dengan sebutan Computer Literacy merujuk pada pemahaman tentang teknologi digital termasuk di dalamnya pengguna dan kemampuan teknis. Kedua, menggunakan Literasi Informasi (Information Literacy). Literasi ini memfokuskan pada satu aspek pengetahuan, seperti kemampuan untuk memetakan, mengidentifikasi, mengolah, dan menggunakan informasi digital secara optimal. Konsep literasi digital, merupakan kecakapan (life skills) yang tidak hanya melibatkan kemampuan menggunakan perangkat teknologi, informasi, dan komunikasi, tetapi juga kemampuan bersosialisasi, kemampuan dalam pembelajaran, dan memiliki sikap, berpikir kritis, kreatif, serta inspiratif sebagai kompetensi digital. ${ }^{9}$ Adapun prinsip dasar pengembangan literasi digital, antara lain, sebagai berikut:

\section{Pemahaman}

Prinsip pertama dari literasi digital adalah pemahaman sederhana yang meliputi kemampuan untuk mengekstrak ide secara implisit dan ekspilisit dari media.

\section{Saling Ketergantungan}

Prinsip kedua dari literasi digital adalah saling ketergantungan yang dimaknai bagaimana suatu bentuk media berhubungan dengan yang lain secara potensi, metaforis, ideal, dan harfiah. Dahulu jumlah media yang sedikit dibuat dengan tujuan untuk mengisolasi dan penerbitan menjadi lebih mudah daripada sebelumnya. Sekarang ini dengan begitu banyaknya jumlah media, bentuk-bentuk media diharapkan tidak hanya sekadar berdampingan, tetapi juga saling melengkapi satu sama lain.

\section{Faktor Sosial}

Berbagi tidak hanya sekadar sarana untuk menunjukkan identitas pribadi atau distribusi informasi, tetapi juga dapat membuat pesan tersendiri. Siapa yang membagikan informasi, kepada siapa informasi itu diberikan, dan melalui media apa informasi itu berikan tidak hanya dapat menentukan keberhasilan jangka panjang

${ }^{9}$ Departemen Pendidikan Nasional, Materi Pendukung Literasi Digital (Jakarta: Kementrian Pendidikan dan Kebudayaan, 2017). 
media itu sendiri, tetapi juga dapat membentuk ekosistem organik untuk mencari informasi, berbagi informasi, menyimpan informasi, dan akhirnya membentuk ulang media itu sendiri.

\section{Kurasi}

Berbicara tentang penyimpanan informasi, seperti penyimpanan konten pada media sosial melalui metode "save to read later" merupakan salah satu jenis literasi yang dihubungkan dengan kemampuan untuk memahami nilai dari sebuah informasi dan menyimpannya agar lebih mudah diakses dan dapat bermanfaat jangka panjang. Kurasi tingkat lanjut harus berpotensi sebagai kurasi sosial, seperti bekerja sama untuk menemukan, mengumpulkan, serta mengorganisasi informasi yang bernilai. ${ }^{10}$

Sedangkan pendekatan pengembangan yang dapat dilakukan pada literasi digital mencakup dua aspek, yaitu pendekatan konseptual dan operasional. Pendekatan konseptual berfokus pada aspek perkembangan koginitif dan sosial emosional, sedangkan pendekatan operasional berfokus pada kemampuan teknis penggunaan media itu sendiri yang tidak dapat diabaikan. Lebih lanjut, prinsip pengembangan literasi digital menurut Mayes dan Fowler dalam modul Gerakan Lierasi Nasional Kementrian Pendidikan dan Kebudayaan bersifat berjenjang. Terdapat tiga tingkatan pada literasi digital. Pertama, kompetensi digital yang meliputi keterampilan, konsep, pendekatan, dan perilaku. Kedua, penggunaan digital yang merujuk pada pengaplikasian kompetensi digital yang berhubungan dengan konteks tertentu. Ketiga, transformasi digital yang membutuhkan kreativitas dan inovasi pada dunia digital. ${ }^{11}$

\section{Metode Penelitiaan}

Penelitian ini merupakan penelitian lapangan (field research) yang bersifat kuantitatif. Peneliti mengumpulkan data menggunakan instrumen daftar cek perilaku (behavioral checklist) yang berupa skala persentase sikap responden penelitian. ${ }^{12}$ Adapun populasi penelitian difokuskan kepada seluruh mahasiswa Prodi PGMI Fakultas Tarbiyah Institut Agama Islam (IAI) Muhammadiyah Bima, berjumlah 128 orang. Namun yang menjadi sampel penelitian sebanyak 30 orang yang ambil secara acak menggunakan teknik stratified random sampling (1).Pendekatan yang digunakan dalam penelitian ini adalah pendekatan kuantitatif deskriptif. Melalui pendekatan ini memungkinkan bagi peneliti untuk mengukur indeks litersi digital mahasiswa keguruan dalam menghadapi era revolusi industri 4.0 mencakup; persepsi

\footnotetext{
${ }^{10}$ Ibid.

11 Ibid.

12 Emzir, Metodologi Penelitian Pendidikan Kuantitatf dan Kualitatif (Jakarta: PT Rajawali Pers, 2012).
} 
mahasiswa terhadap literasi digital dalam mengahadapi era revolusi industri, keterpaparan para mahasiswa dalam menggunakan teknologi digitalera revolusi industri, dan harapan para mahasiswa tentang pengembangan literasi digital di era revolusi industri.

\section{Hasil dan Pembahasan Penelitian}

\section{Persepsi Mahasiswa Terhadap Literasi Digital Dalam Mengahadapi Era Revolusi Industri 4.0}

Perkembangan teknologi digital di era revolusi industri tidak hanya mempengaruhi segmen kehidupan masyarakat secara umum, namunmahasiswa sebagai kelompok sosial masyarakatpadadiunit akademik ilmiah juga dihadapkan dengan geliat pemanfaatan terkologi digital dalam menunjang aktivitas perkuliahan. Kondisi ini pun turut memengaruhi ragam pandangan/persepsi para mahsiswa terkiat urgensinya literasi digital dalam mengahadapi era revolusi industri.Berdasarkan hasil analisis angket penilitian yang dilakukan penulis khususnya pada mahasiswa keguruanProdi PGMI Fakultas Tarbiyah Institut Agama Islam (IAI) Muhammadiyah Bima, menunjukan bahwa skala rata-rata persepsi mahasiswa tentang literasi digital adalah $63 \%$ yang termasuk pada kategori sedang. Meskipun secara menyeluruh umumnya mahasiswa menilai penting dan mendukung pengguanaan teknologi digital sebagai basis pengembangan diri di era revolusi industry 4.0. Hal ini dapat dilihat pada deskripsi tentang grafik tingtkatpersepsi mahasiswa sebagai berikut:

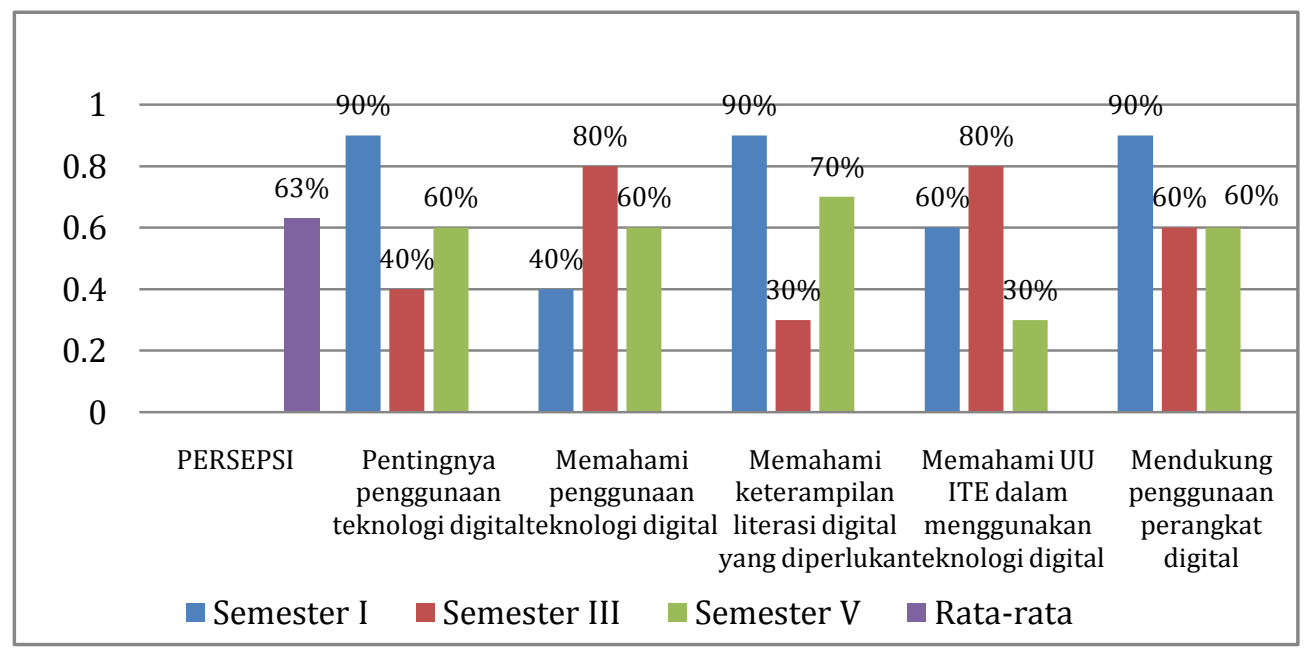

Gambar 1. Grafik Tingkat Persepsi Mahasiswa Terhadap Literasi Digital

Berdasarkan data grafik persepsi mahasiswa di atas, menarikanya jika dilihat dari tingkat semester mahasiswa menunjukan tingkat persepsi yang berbeda tentang liresi digital. Semester I menunjukan tingkat persepsi yang lebih tinggi dengan skala 
rata-rata 90\% pada aspek yang mencakup; pentingnya penggunaan teknologi digital, memahami keterampilan digital yang diperlukan, dan mendukung penggunaan perangkat digital dalam aktivitas pembelajaran. Sedangkan pada semester III dan V menunjukan skala persentasi berada pada kategori sedang (60\%) pada aspek yang sama. Kondisi tersebut, menurut hemat penulis termasuk hal yang lumrah terjadi, terutama peningkatan penggunaan teknologi digital di semester I, dikarenkan faktor transisi usia remaja ke kedewasa yang masih kuat rasa ingin tahunya terutama dalam penggunaan teknologi dan aplikasi digital.

Tingginya tingkat literasi digital pada semester I juga didorong oleh tren percepatan penggunaan aplikasi digital beberapa tahun terakhir, sehingga turut mempengaruhi animo para mahasiswa untuk berusaha lebih up to date dengan perkembangan litersi digital. Hal ini sejalan dengan penelitian sebelumnya yang dilakukanQory Qurratun A'yuni, mengungkapkan tingginya tingkat kompetensi literasi digital remaja di Kota Surabaya diukur menggunakan sejumlah kompetensi terutama padaaspek pencarian di internet (internet searching), dan penyusunan pengetahuan (knowledge assembly) dengan skala rata-rata berada pada kategori tinggi. ${ }^{13}$ Selanjutnya,dilihat dari aspek memahami penggunaan teknologi digitalbaik disemester I, II, dan II secara keseluruhan para mahasiswa menunjukan tingkat pemahaman berada pada kategori sedang (60\%). Hal ini sejalan dengan data penelitian yang ditemukan di Medan oleh Stella Stefani, dkk., tahun 2017 bahwa penggunaan teknologi digital di Kota Medan masuk kategori baik/sedang (69\%). Dimana sebagian besar responden menyakatakan tidak mengalami kesulitan dalam penggunaan teknologi digital. ${ }^{14}$

\section{Keterpaparan Mahasiswa Dalam Menggunakan Teknologi Digital Era Revolusi Industri 4.0}

Kemampuan literasi digital menjadi faktor penunjang dalam kehidupan sosial masyarakat di era revolusi industri. Bahkan konsep dunia dalam genggaman sebagai konsekuensi perkembangan global di seluruh dunia, telah menggiring opini manusia untuk meningkatkan daya penggunaan media digital untuk mempermudah dan mempercepat akses kehidupan di lingkungan sekitar. Pada sisi lainnya, penggunaan media digital turut mempengaruhi paradigma sesorang untuk memenuhi ruang

\footnotetext{
${ }^{13}$ Qory Qurratun A'yuni, Studi Deskriptif tentang Tingkat Kompetensi Literasi Digital pada Remaja SMP, SMA dan Mahasiswa di Kota Surabaya. Departemen Informasi dan Perpustakaan, Fakultas Ilmu Sosial dan Ilmu Politik, Universitas Airlangga Surabaya.

${ }^{14}$ Stella Stefani, dkk. Literasi Digital Dan Pembukaan Diri: Studi Korelasi Penggunaan Media Sosial Pada Pelajar Remaja di Kota Medan. (Sosioglobal: J Pemikiran dan Penelitian Sosiologi, 2017), 19-20.
} 
keterbatas informasi, peluang maupun tentang hidup yang selarah dengan perubahan zaman yang serba digitalisasi. Kondisi tersebut juga mempengaruhi aktivitas akademik mahasiswa yang dituntut untuk lebih upto date dengan segala perkembangan di era revolusi industry 4.0 seperti sekarang ini. Berdasarkan hasil analisis angket penelitian yang dilakukan penulis khususnya pada mahasiswa keguruan Prodi PGMI Fakultas Tarbiyah Institut Agama Islam (IAI) Muhammadiyah Bima, menunjukan bahwa skala rata-rata keterpaparan mahasiswa dalam menggunakan teknologi digital adalah 33\% yang termasuk pada kategori rendah. Meskipun pada satu sisi, terdapat sebagian kecil mahasiswa yang menyatakan terbiasa menggunakan media digital untuk mendukung aktivitas akdemiknya. Hal ini dapat dilihat pada deskripsi tentang grafik tingkat keterpaparan mahasiswa dalam menggunakan media digital sebagai berikut:

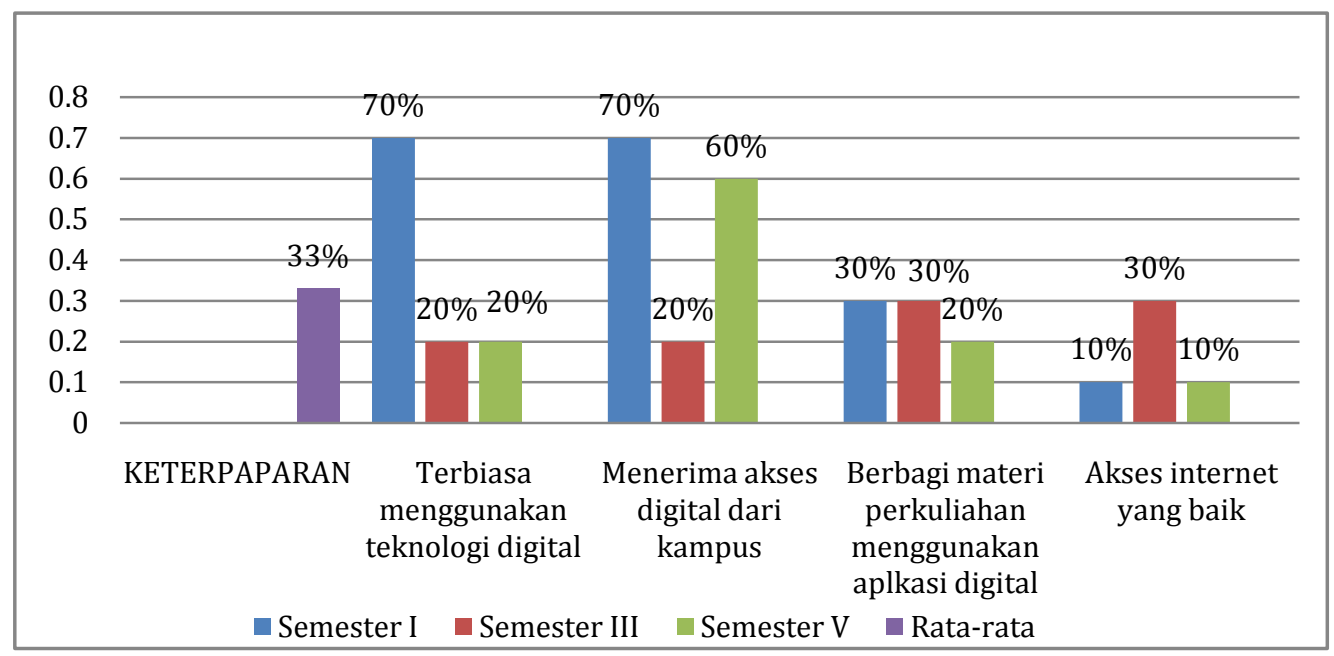

Gambar 2. Grafik Ket erpaparan Mahasiswa terhadap Teknlogi Digital

Berdasarkankan data grafik di atas, keterpaparan mahasiswa terhadap teknologi digital di atas,maka dapat diketahui bahwa hal yang menonjol adalah adanya kesenjangan yang cukup signifikan pada mahasiswa semester I dengan mahasiswa semester III dan V. Dimana diketahui bahwa mahasiswa semester I memiliki tingkat keterpaparan yang lebih tinggi daripada mahasiswa dua tingkat di atasnya. Selanjutnya, merujuk hasil analisis angket yang disebar, diketahui bahwa 100\% mahasiswa yang menjadi sampel penelitian memiliki akun sosial media berupa Facebook. Namun pada mahasiswa semester I, terdapat beberapa mahasiswa yang memiliki akun media sosial lain seperti Instagram, hal ini yang jarang ditemukan pada mahasiswa semester III dan V. Bahkan dari 10 orang yang dijadikan sampel penelitian di semester I, ditemukan 3 orang yang memiliki akun Youtube dan 1 orang 
yang sudah memiliki blog. Hal ini yang menjadikan mahasiswa-mahasiswa tersebut terbiasa menggunakan teknologi digital.

Namun sayangnya, keberadaan teknologi digital berupa aplikasi sosial media yang mereka miliki tidak dimanfaatkan dengan baik untuk mendukung pembelajaran dengan cara berbagi materi maupun informasi terkait perkuliahan. Hal ini terlihat dari Gambar bahwa tingkat kecenderungan mahasiswa untuk memanfaatkan aplikasi digital dalam berbagi materi perkuliahan hanya $20-30 \%$. Hal ini kontras dengan data yang didapat pada Gambar 1 yang menunjukan tingginya dukungan mahasiswa terhadap penggunaan perangkat digital. Setelah ditelusuri lebih lanjut, diketahui bahwa apresiasi mahassiwa terhadap aplikasi digital terbatas pada penggunaan sosial media untuk memperluas jaringan pertemanan semata dan mengikuti tren perkembangan jaman, bukan untuk meningkatkan pengetahuan dan informasi terhadap konten-konter perkuliahan. Hal ini diketahui dengan minimnya penggunaan surat elektronik (email) untuk keperluan kuliah.

Keterpaparan terhadap teknologi digital seharusnya didukung oleh baiknya akses internet yang memungkinkan pengguna mengakses aplikasi digital yang disediakan oleh perbagai penyedia layanan digital. Namun, fakta yang ditemukan pada penelitian ini bahwa baiknya akses internet yang dimiliki oleh mahasiswa masih sangat rendah (17\%) terutama ditingkat layanan publik secara umum mapun pada aspek layanan di tingkat akademik. Hal ini jelas membatasi mahasiswa dalam mencari informasi untuk meningkatkan kompetensi dirinya. Padahal, bila ditinjau dalam wacana gerakan literasi nasional sebagaimana yang dicanangkan Kementrian Pendidikan dan Kebudayaan pada Tahun 2017 mengkapkan bahwa pentingnya perluasan akses sumber belajar dan cakupan peserta belajar yang mecakup beberapa hal antara lain:

Pertama, Penyediaan Akses internet di ruang publik yang beruapa sumber belajar yang dibutuhkan dapat diperoleh dengan menggunakan akses internet dengan sangat cepat dan efisien. Kebutuhan masyarakat dalam memperoleh pengetahuan dan mengasah keterampilan harus ditunjang oleh kesediaan oleh akses internet yang ada di masyarakat. Misalnya, di desa terdapat pojok internet khusus yang disediakan untuk masyarakat; pada ruang publik lainnya, seperti perpustakaan umum, terminal, bandara, pelabuhan dapat disediakan akses internet untuk masyarakat. Kedua, Penyediaan informasi melalui media digital di ruang publik berupa penyediaan layar dan papan informasi digital di ruang publik dapat membantu masyarakat dalam memperoleh informasi dan pengetahuan baru. Layar informasi yang ada di bandara,stasiun, terminal, pelabuhan, persimpangan jalan strategis, dan pasar dapat diisi dengan konten-konten perkembangan ilmu pengetahuan dunia, fakta-fakta sains 
sederhana, berita-berita terkini, permainan edukatif, dan sebagainya. Semuanya dapat ditampilkan dan disediakan sebagai penambahan wawasan masyarakat. ${ }^{15}$

\section{Harapan Mahasiswa terhadap Pengembangan Literasi Digital Di Era Revolusi Industri 4.0}

Posisi mahasiswa sebagai unit masyarakat ilmiah yang diproyeksi menjadi agen perubahan bagi masa depan kemajuan bangsa dan Negara, terlebih lagi bagi lingkungan sosial masyarakat sepatutnya menjadi landasan filosofis yang dapat mempengaruhi sikap dan perilaku mahasiswa akan pentingnya sebuah pengembangan diri. Kondisi ini juga seharusnya menjadi dasar bagi para mahasiswa agar meningkatkan kompetensi diri dalam menghadapi perubahan dan perkembangan jaman yang serba digital di era revolusi industri 4.0. Namun faktanya, berdasarkan hasil analisis angket penilitian yang dilakukan penulis khususnya pada mahasiswa keguruan Prodi PGMI Fakultas Tarbiyah Institut Agama Islam (IAI) Muhammadiyah Bima, menunjukan skala rata-rata harapan mahasiswa dalam pengembangan literasi digital adalah $42 \%$ masih dalam kategori sedang. Hal ini dapat dilihat pada deskripsi tentang grafik tingkat harapan mahasiswa terhadap pengembangan literasi digital sebagai berikut:

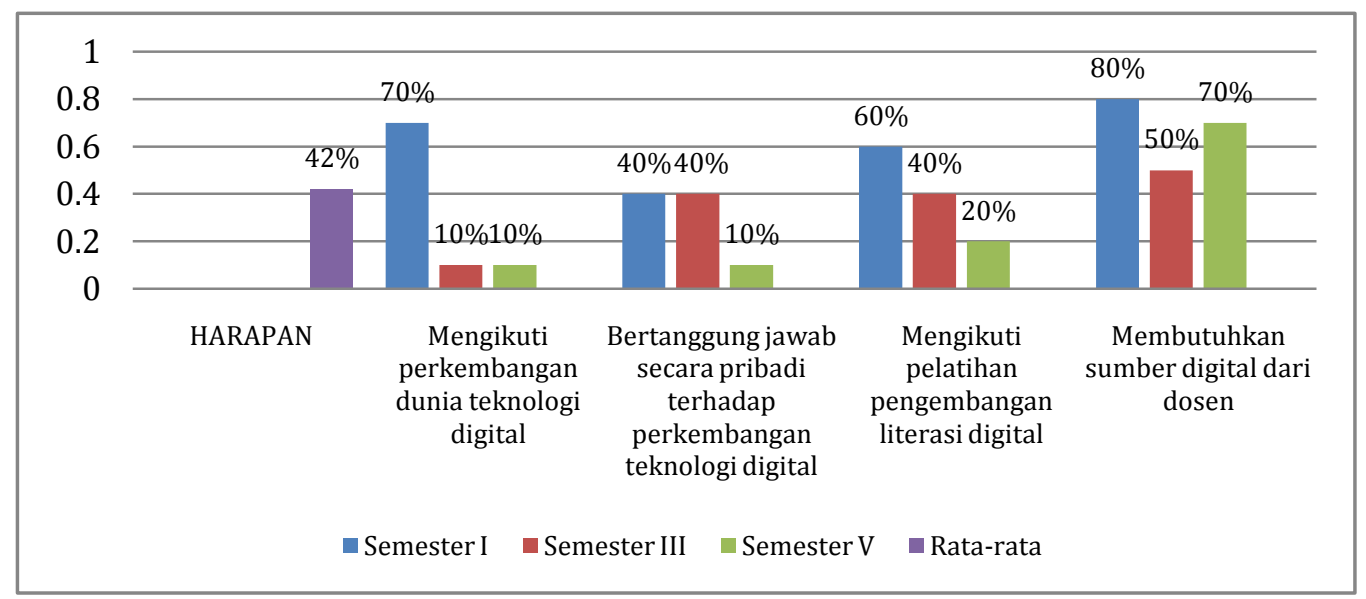

Gambar 3.Grafik Harapan Mahasiswa terhadap Pengembangan Literasi Digital

Berdasarkan grafik di atas diketahui bahwa rata-rata harapan mahasiswa khususnyapada semester I masih menduduki peringkat tertinggi untuk harapan pengembangan literasi digital dibandingkan dengan semester III dan V. Hal yang menonjol dari data pada gambar 3 adalah tingginya rata-rata harapan mahasiswa terhadap sumber digital yang diberikan oleh dosen (67\%). Kondisi ini terjadi karena

${ }^{15}$ Departemen Pendidikan Nasional, Materi Pendukung Literasi Digital (Jakarta: Kementrian Pendidikan dan Kebudayaan, 2017) 
keterbatasan kemampuan mahasiswa dalam mencari, mengelola dan mengakses berbagai sumber pembelajaran online masih terbatas, sehingga mahasiswa membutuhkan bantuan sumber belajar digital yang diberikan oleh para dosen. Dilihat dari aspek kegiatan/keterlibatan para mahasiswa dalam mengikuti pelatihan pengembangan literasi digital dinilai sangat kurang dengan skala rata-rata persentase 40\% yakni masih berada pada kategori sedang. Padahal di satu sisi, tingkat kompetensi literasi digital pada diri mahasiswa termasuk ranah soft skill yang mesti dipenuhi oleh para mahasiswa di era revolusi indutri 4.0. menurut hemat penulis, dengan adanya kemampuan literasi digital yang memadai, paling tidak dapat menjadi sarana pendukung pencarian informasi dan komunikasiserta dapat dimanfaatkansebagai peluang usaha berbasis digital.Bahkan pengembangan literasi digital juga termasuk kerangka capaian nasionalsebagai prasyarat kecakapan hidup abad ke-21 melalui pendidikan yang terintegrasi, mulai dari keluarga, sekolah, sampai dengan masyarakat. Penguasaan enam literasi dasar yang disepakati oleh World Economic Forum pada tahun 2015 menjadi sangat penting tidak hanya bagi peserta didik, tetapi juga bagi orang tua dan seluruh warga masyarakat. Enam literasi dasar mencakup literasi baca tulis, literasi numerasi, literasi sains, literasi digital, literasi finansial, dan literasi budaya dan kewargaan. ${ }^{16}$

Setiap individu perlu memahami bahwa literasi digital merupakan hal penting yang dibutuhkan untuk dapat berpartisipasi di dunia modern sekarang ini. Literasi digital sama pentingnya dengan membaca, menulis, berhitung, dan disiplin ilmu lainnya. Generasi yang tumbuh dengan akses yang tidak terbatas dalam teknologi digital mempunyai pola berpikir yang berbeda dengan generasi sebelumnya. Setiap orang hendaknya dapat bertanggung jawab terhadap bagaimana menggunakan teknologi untuk berinteraksi dengan lingkungan sekitarnya. Teknologi digital memungkinkan orang untuk berinteraksi dan berkomunikasi dengan keluarga dan teman dalam kehidupan sehari-hari. Sayangnya, dunia maya saat ini semakin dipenuhi konten berbau berita bohong, ujaran kebencian, dan radikalisme, bahkan praktik-praktik penipuan. Keberadaan konten negatif yang merusak ekosistem digital saat ini hanya bisa ditangkal dengan membangun kesadaran dari tiap-tiap individu. Menjadi literasi digital berarti dapat memproses berbagai informasi, dapat memahami pesan dan berkomunikasi efektif dengan orang lain dalam berbagai bentuk. Dalam hal ini, bentuk yang dimaksud seperti menciptakan, mengolaborasi, mengomunikasikan, bekerja sesuai dengan aturan etika, dan memahami bagaimana teknologi harus digunakan agar efektif untuk mencapai tujuan, termasuk juga kesadaran dan berpikir

\footnotetext{
${ }^{16}$ Departemen Pendidikan Nasional. Materi Pendukung Literasi Digital..., op.cit
} 
kritis terhadap berbagai dampak positif dan negatif yang mungkin terjadi akibat penggunaan teknologi dalam kehidupan sehari-hari. Memacu individu untuk beralih dari konsumen informasi yang pasif menjadi produsen aktif, baik secara individu maupun sebagai bagian dari komunitas. Jika generasi muda kurang menguasai kompetensi digital, hal ini sangat berisiko bagi mereka untuk tersisih dalam persaingan memperoleh pekerjaan, partisipasi demokrasi, dan interaksi sosial. ${ }^{17}$

\section{Penutup}

Berdasarkan hasil penelitian dan pembahasan, maka dapat disimpulkan bahwa tingkat literasi digitalmahasiswa keguruan Prodi PGMI Fakultas Tarbiyah Institut Agama Islam (IAI) Muhammadiyah Bima dilihat dari aspek persepsi terhadap literasi digital berada pada kategori sedang (63\%), aspek keterpaparan terhadap teknologi digital menempati kategori rendah (33\%), dan untuk aspek harapan terhadap pengembangan literasi digital masuk pada kategori sedang (42\%). Meskipun terdapat berapa indikator aspek yang menunjukan tingkat persepsi, keteraparan, maupun harapan mahasiswa terhadap pengembangan litersai digital masih dinilai sangat kurang. Dengan demikian, perlu diupuyakan penguatan kapasitas literasi digital bagi para mahasiswa keguruan sehingga mampu menjawab tantangan dan memanfaatkan peluang di era revolusi industri 4.0

\section{DAFTAR PUSTAKA}

A'yuni, Qory Qurratun. Studi Deskriptif tentang Tingkat Kompetensi Literasi Digital pada Remaja SMP, SMA dan Mahasiswa di Kota Surabaya. Departemen Informasi dan Perpustakaan, Fakultas Ilmu Sosial dan Ilmu Politik, Universitas Airlangga Surabaya.

Departemen Pendidikan Nasional.Materi Pendukung Literasi Digital. Jakarta: Kementrian Pendidikan dan Kebudayaan, 2017.

Emzir. Metodologi Penelitian Pendidikan Kuantitatf dan Kualitatif. Jakarta: PT Rajawali Pers, 2012.

Herlina S. Dyna. Membangun Karakter Bangsa melalui Literasi Digital.pdf.

Kurnianingsih, Indah dkk. Upaya Peningkatan Kemampuan Literasi Digital bagi

Tenaga Perpustakaan Sekolah dan Guru di Wilayah Jakarta Pusat Melalui Pelatihan Literasi Informasi. JPKM 3: 62-63, 2017.

Prasetyo, Bambang dan Lina Maftahul Jannah. Metode Penelitian Kuantitatif. Jakarta: PT Rajawali Pers, 2014.

\footnotetext{
${ }^{17}$ Ibid.,
} 
Stefani, Stella dkk. Literasi Digital Dan Pembukaan Diri: Studi Korelasi Penggunaan Media Sosial Pada Pelajar Remaja di Kota Medan. Sosioglobal: J Pemikiran dan Penelitian Sosiologi, 2: 19-20, 2017.

Yahya, Muhammad. Era Industri 4.0: Tantangan dan Peluang Perkembangan Pendidikan Kejuruan Indonesia.Pidato Pengukuhan Penerimaan Jabatan Professor Tetap dalam Bidang Ilmu Pendidikan Kejuruan Fakultas Teknik Universitas Negeri Makassar, 2018. 